\title{
EFFECTS OF DIFFERENT FOREST RECONSTRUCTION METHODS ON CHARACTERISTICS OF UNDERSTORY VEGETATION AND SOIL QUALITY
}

\author{
GUO, X. F. ${ }^{1,2}$ \\ ${ }^{1}$ College of Environmental Science and Engineering, China West Normal University \\ Nanchong, China \\ ${ }^{2}$ College of Resources and Environmental Sciences, South China Agricultural University \\ Guangzhou, China
}

(e-mail: gxfcwnu@qq.com; phone: +86-17778382606)

(Received $6^{\text {th }}$ Jun 2018; accepted $5^{\text {th }}$ Oct 2018)

\begin{abstract}
The effects of different afforestation methods on the soil quality of the woodland was discussed. This paper took several afforestation lands reformed by four Miyawaki Methods and one traditional method respectively and an untransformed woodland in Nanhai District, Foshan City, China as the research objects, and conducted the comparative analysis on the soil physical, chemical characteristics and biological characteristics of different woodlands. The results showed that the average coverage of understory shrub layer and herbaceous layer of each type of reformed woodland from large to small was GX3 $>$ GX2 $>\mathrm{CT}>\mathrm{GX} 1>\mathrm{GX} 4>\mathrm{CK}$. The change of the biomass of herbaceous layer was consistent with the total biomass, and the order from large to small both was GX2>GX3>GX1>CT $>\mathrm{GX} 4>\mathrm{CK}$. There was no significant difference in the effects of different afforestation methods on soil physical properties. The Miyawaki Method 2 afforestation land had the highest soil organic matter content. The Miyawaki Method 3 afforestation land had the highest soil total nitrogen, available nitrogen and available potassium content, the number of the bacteria, fungus and actinomycetes and soil enzyme activities. The traditional method afforestation land had the highest soil total phosphorus and available phosphorus content. The analysis results of principal component showed that the comprehensive index of soil quality in different afforestation methods was: $\mathrm{GX} 3>\mathrm{GX} 1>\mathrm{GX} 2>\mathrm{CT}>\mathrm{GX} 4>\mathrm{CK}$, which indicated that the transformation could improve the soil quality effectively, and the transformation efficiency in the Miyawaki Method 3 was the best. So the transformation efficiency should be mainly considered in the transformation practice. Keywords: Miyawaki Method; soil physic-chemical properties; vegetation; microorganism; enzyme activities
\end{abstract}

\section{Introduction}

The soil quality can be used as an indicative factor to measure the ability of soil to provide good environmental conditions for vegetation growth and development, and it is a comprehensive reflection of soil physical and chemical properties and biological properties (Schoenholtz et al., 2000; Jaurixje et al., 2013). As a highly concerned means of ecological restoration, the afforestation can play a role in preventing wind and sand fixation, reducing water and soil loss, enhancing land productivity and improving the ecological environment (Akca et al., 2010; Berthrong et al., 2009; Chen et al., 2008; Wang et al., 2014). There are more studies on the mutual relation between afforestation and soil characteristic change and few studies on the impact of different afforestation methods on soil properties. The Miyawaki Method is the afforestation method of rapid vegetation restoration based on the community succession theory. This afforestation method advocates the construction of forest with native trees (Miyawaki et al., 1993; Schirone et al., 2011; Miyawaki, 1998), which has low construction cost, less artificial 
control, shortened self-cultivating forest time, rich species, complete community structure and other advantages compared with the traditional afforestation method.

In order to discuss the effect of Miyawaki Method and the common afforestation method (traditional method) on forest soil and understory vegetation, five different afforestation methods were carried out in Danzao Town, Nanhai District, Foshan City, Guangdong Province, China based on the Miyawaki Method and traditional method technology. The mutual relation between forest soil quality and understory vegetation characteristics of different afforestation methods was discussed, which provided the scientific basis for the selection of afforestation methods. This research was fundamental to improve plant diversity of forest communities and transformed degraded forestland efficiently.

\section{Materials and Methods}

\section{Overview of the research area}

The research area is located in forestry station in Nanhai District, Foshan City, Guangdong Province, China $\left(23^{\circ} 01 \mathrm{~N}, 112^{\circ} 54^{\prime} \mathrm{E}\right)$, with an annual average temperature of $22^{\circ} \mathrm{C}$, an average temperature in Jul. of $28.8^{\circ} \mathrm{C}$, an average temperature in Jan. of $13.3^{\circ} \mathrm{C}$ and an annual average rainfall precipitation of $1702 \mathrm{~mm}$. It has less frost days and a long frost-free period. The terrain is flat, with fish ponds in the southwest and low hills and terraces in the northwest. After logging in April 2006, the dominant trees in the study area have been destroyed, and the main forest type was degraded secondary forest. Through the field investigation, the main vegetation in the research area includes Litsea glutinosa, Schima argentea, Eucalyptus uraphylla, Lysidice rhodostegia, Trema tomentosa, Toxicodendron succedaneum, Cinnamomum burmanni and Syzygium jambos, Dicranopteris pedata, etc. In general, the number of vegetation was small, and the community structure was incomplete, which needed to carry out the transformation. The location of sampling site was shown in Figure 1 which was generated by the software of Google Earth.

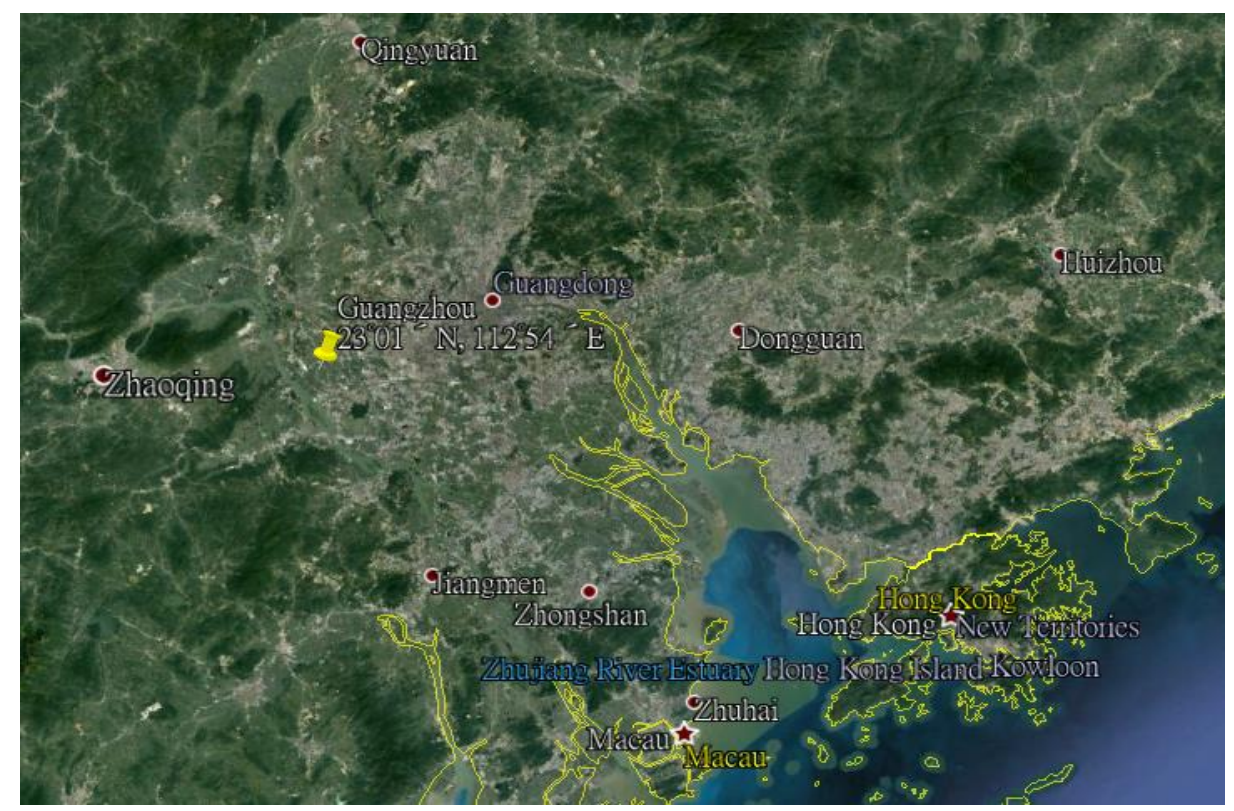

Figure 1. GPS coordinates of the sampling site 
In 2007, the sample plots were classified as experimental plots. Some of the woodlands were reformed by traditional methods and Miyawaki Method and untransformed woodlands were used as control plots. The main transformed species were Eucalyptus urophylla and Cinnamomum burmanni. The dominant species in the transformed woodlands were shown in Table 1 and the photos showing the habitat of experimental sites were also given in Figure 2.

Table 1. Vegetation characterisation in reforestland

\begin{tabular}{c|c}
\hline Transformation type & Major Species \\
\hline Miyawaki Method & $\begin{array}{c}\text { Eucalyptus urophylla, Pinus massomiana, Psilopeganum sinense, Syzygium } \\
\text { jambos, Cinnamomum burmanni, Lantana camara, Acacia farnesiana, } \\
\text { Nerium indicum, Pennisetum purpureum, Dicranopteris dichotoma }\end{array}$ \\
\hline \multirow{2}{*}{ Traditional method } & $\begin{array}{c}\text { Eucalyptus urophylla, Pinus massomiana, Psilopeganum sinense, Cyclosorus } \\
\text { parasiticus, Acacia farnesiana, Nerium indicum, Conyza canadensis, } \\
\text { Control }\end{array}$ \\
\hline Lysidice rhodostegia, Schima argentea, Nerium indicum, Conyza canadensis, \\
Pennisetum purpureum, Dicranopteris dichotoma
\end{tabular}

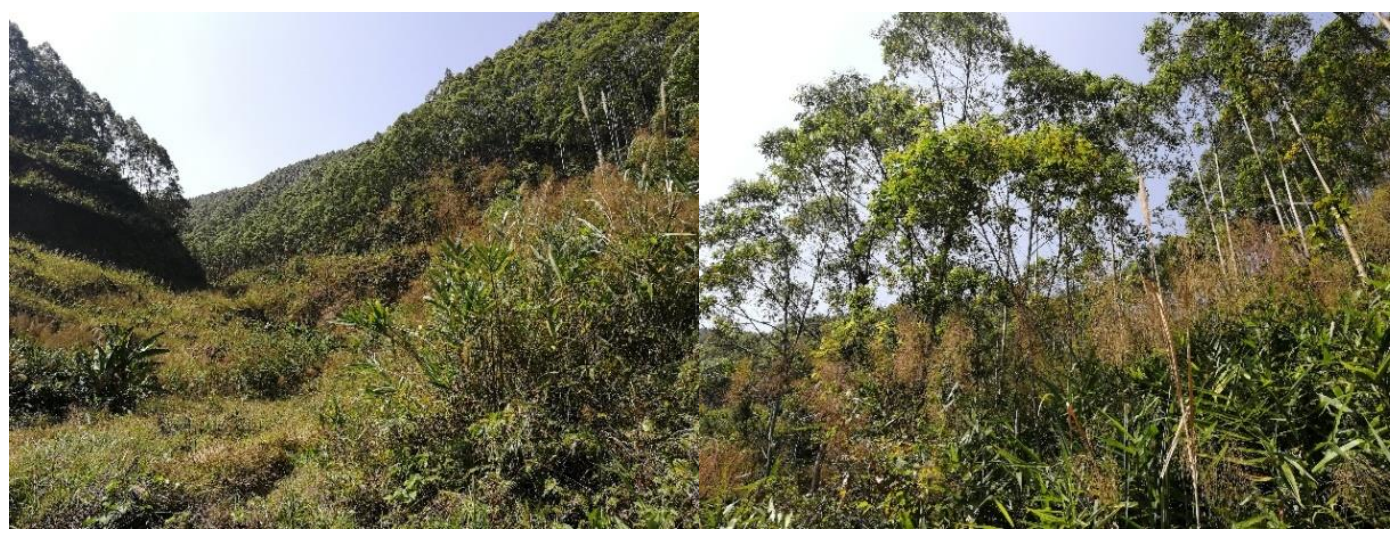

Figure 2. Photos showing the habitat of experimental sites

The research area belongs to the concentrated low hill, and the soil type is the common mountain acid latosolic red soil in the south, with large annual precipitation, strong water and fertilizer liquidity and rare native vegetation. Therefore, there is no significant difference in soil fertility before the transformation. The results of soil quality basically reflect the effects of different afforestation methods on soil quality after the transformation.

\section{Research method}

\section{Establishment and investigation of sample plot}

3 sample plots for $10 \mathrm{~m} \times 10 \mathrm{~m}$ were set up in 4 Miyawaki Method experimental areas of Danzao Town, Nanhai District, Foshan City, and 3 sample plots for $20 \mathrm{~m} \times 20 \mathrm{~m}$ were set up in traditional method control areas. A single sample plot is used as a basic unit to investigate the experimental areas. The basic situation of the transformed forest and afforestation techniques were shown in Table 2. 
Table 2. The basic background situation in the Standard land

\begin{tabular}{|c|c|c|c|c|c|c|c|c|}
\hline Transformation type & $\begin{array}{l}\text { Code } \\
\text { name }\end{array}$ & Slope & $\begin{array}{c}\text { Aspect } \\
\left({ }^{\circ}\right)\end{array}$ & $\begin{array}{c}\text { Slope } \\
\text { Position }\end{array}$ & $\begin{array}{l}\text { Canopy } \\
\text { density }\end{array}$ & $\begin{array}{c}\text { Afforestation } \\
\operatorname{area}\left(\mathbf{h m}^{2}\right)\end{array}$ & $\begin{array}{c}\text { Afforestation } \\
\text { density }\end{array}$ & Afforestation Measures \\
\hline Miyawaki Method 1 & MM1 & - & 0 & - & 0.7 & 0.131 & 4 plants $/ \mathrm{m}^{2}$ & $\begin{array}{c}\text { Afforestation land } \\
\text { preparation, base fertilizer, no } \\
\text { top dressing }\end{array}$ \\
\hline Miyawaki Method 2 & MM2 & - & 0 & - & 0.8 & 0.154 & 4 plants $/ \mathrm{m}^{2}$ & $\begin{array}{c}\text { Afforestation land } \\
\text { preparation, no base fertilizer, } \\
\text { top dressing }\end{array}$ \\
\hline Miyawaki Method 3 & MM3 & - & 0 & - & 0.6 & 0.135 & 2 plants $/ \mathrm{m}^{2}$ & $\begin{array}{l}\text { Afforestation land } \\
\text { preparation, base fertilizer, no } \\
\text { top dressing }\end{array}$ \\
\hline Miyawaki Method 4 & MM4 & $\mathrm{W}$ & 7 & downside & 0.6 & 0.135 & 2 plants $/ \mathrm{m}^{2}$ & $\begin{array}{c}\text { Afforestation land } \\
\text { preparation, no base fertilizer, } \\
\text { top dressing }\end{array}$ \\
\hline Traditional method & $\mathrm{T}$ & $\mathrm{E} 30^{\circ} \mathrm{S}$ & 6 & middle & 0.5 & 1.047 & 1665 plants $/ \mathrm{hm}^{2}$ & $\begin{array}{c}\text { Afforestation land } \\
\text { preparation, base fertilizer, top } \\
\text { dressing }\end{array}$ \\
\hline Control & $\mathrm{C}$ & $\mathrm{N} 10^{\circ} \mathrm{W}$ & 6 & downside & 0.6 & 0.301 & & No stand improvement \\
\hline
\end{tabular}

In the sloping column, the $\mathrm{E} 30^{\circ} \mathrm{S}$ indicates 30 degrees east of the south. The control is the unreconstructed woodland 


\section{Understory vegetation survey and biomass calculation}

A small sample of $4 \mathrm{~m} \times 4 \mathrm{~m}$ in each corner of the four standard plots was set up to investigate the coverage and height of shrubs and herbaceous layers. For each sample, one $2 \mathrm{~m} \times 2 \mathrm{~m}$ shrub quadrat $1 \mathrm{~m} \times 1 \mathrm{~m}$ herb quadrat were set up. The biomass (including the roots, stems and leaves of shrubs and the aboveground and underground parts of herbs) was measured by harvesting method. The fresh weight of the plant samples was weighed and then taken to the laboratory separately. The plant moisture content was calculated by drying, crushing and weighing. The dry matter mass (biomass) in each small quadrat was calculated, and the biomass of a standard ground was finally calculated.

\section{Collection and determination of soil samples}

Five sampling points were set up in the sample plots according to the $S$ shape, and the soil auger was used to collect five soil samples for $0 \sim 20 \mathrm{~cm}$ and 1 cutting ring sample soil, then, the stone and plant roots were removed. The soil samples collected at the same five sampling points were fully mixed into the mixed soil samples, and the quartering method was used to collect about $1 \mathrm{~kg}$ as the sample soil for such sample plot. Each afforestation method was repeated for three times, and the sample was used for the determination of soil physical and chemical properties and biological properties after removing impurities, drying, grinding and sieving. The methods to measure soil physicchemical parameters were shown in Table 3.

Table 3. The determination methods of soil physic-chemical parameters

\begin{tabular}{c|c}
\hline Transformation type & Afforestation Measures \\
\hline The nature of soil water content & Drying method \\
\hline Soil bulk density & Ring shear testing \\
\hline Capillary moisture capacity of Soil & Ring shear testing \\
\hline Soil total porosity & Ring shear testing \\
\hline Soil pH & Potentiometer method \\
\hline Soil organic matter content & Potassium chromate volumetric analysis method \\
\hline Soil Total N content & Semimicro-kjeldahl method \\
\hline Soil available N content & Sodium hydroxide alkali fusion-molybdenum blue \\
Soil Total P content & Sodium carbonate extraction-molybdenum blue colorimetry \\
method
\end{tabular}

\section{Evaluation method of soil quality}

The PCA method is the most commonly used in the various comprehensive analysis methods for evaluating soil quality (Zhao et al., 2014; Ranjbar et al., 2016). In the 
research, fifteen factors, including soil physical and chemical property factors (soil bulk density, total porosity, natural moisture content, organic matter, total nitrogen, total potassium, available nitrogen, available phosphorus, available potassium), soil enzyme active factors (urease, phosphatase, catalase), soil microbial factors (bacteria, fungus, actinomycetes) were selected as the PCA comprehensive evaluation index.

\section{Data preprocessing}

SPSS18.0 and Excel 2007 were used for the data statistics and graphics processing. The effects of different afforestation methods on soil physical, chemical and biological properties were inspected by a single factor ANOVA and LSD analysis. PCA was used to calculate the soil quality index of different afforestation methods.

\section{Results and Analysis}

\section{Understory vegetation characteristics}

\section{The coverage and height of understory vegetation}

The average coverage and height of understory vegetation layer (shrub and herb layer) are shown in Table 4. It was known that the average coverage of the shrubs of each type of reformed woodland was in the range of $6.93 \%$ 19.65\% and the height was $0.59 \sim 0.79 \mathrm{~m}$. The average coverage of the herb layer was $33.89 \% \sim 93.65 \%$, and the height was $0.48 \sim 0.55 \mathrm{~m}$. The average coverage of shrub layer and herb layer were arranged in order: GX3 > GX2 > CT> GX1 > GX4 >CK. The average height of shrub layer and herbaceous layer were arranged in order: $\mathrm{CT}>\mathrm{GX} 1>\mathrm{GX} 3>\mathrm{GX} 4>\mathrm{GX} 2>$ $\mathrm{CK}$ and $\mathrm{GX} 4>\mathrm{CK}>\mathrm{GX} 3>\mathrm{GX} 2>\mathrm{GX} 1>\mathrm{CT}$, respectively. However, on the whole, the average height difference was not obvious.

Table 4. The average coverage, height and biomass of shrubs and herbaceous layers in different afforestation land

\begin{tabular}{|c|c|c|c|c|c|c|c|}
\hline \multirow{2}{*}{$\begin{array}{l}\text { Afforestation } \\
\text { method }\end{array}$} & \multicolumn{2}{|c|}{ Average coverage (\%) } & \multicolumn{2}{|c|}{ Average Height (m) } & \multicolumn{3}{|c|}{$\operatorname{Biomass}\left(/ \mathbf{t} \cdot \mathbf{h m}^{-2}\right)$} \\
\hline & Shrub layer & Herb layer & Shrub layer & Herb layer & $\begin{array}{l}\text { Shrub } \\
\text { layer }\end{array}$ & Herb layer & Total \\
\hline MM1 & $11.85 \pm 2.31$ & $56.37 \pm 12.23$ & $0.76 \pm 0.18$ & $0.49 \pm 0.07$ & $0.76 \pm 0.06$ & $7.93 \pm 1.91$ & $8.69 \pm 1.23$ \\
\hline MM2 & $18.55 \pm 3.21$ & $83.65 \pm 21.14$ & $0.63 \pm 0.06$ & $0.52 \pm 0.09$ & $0.78 \pm 0.11$ & $9.01 \pm 2.34$ & $9.79 \pm 1.86$ \\
\hline MM3 & $19.65 \pm 4.53$ & $93.65 \pm 9.68$ & $0.74 \pm 0.11$ & $0.51 \pm 0.17$ & $0.82 \pm 0.14$ & $8.96 \pm 3.12$ & $9.78 \pm 2.07$ \\
\hline MM4 & $11.01 \pm 2.13$ & $39.00 \pm 11.63$ & $0.68 \pm 0.03$ & $0.55 \pm 0.13$ & $0.59 \pm 0.09$ & $6.26 \pm 1.32$ & $6.85 \pm 1.73$ \\
\hline $\mathrm{T}$ & $12.64 \pm 3.91$ & $76.12 \pm 15.34$ & $0.79 \pm 0.21$ & $0.48 \pm 0.08$ & $0.67 \pm 0.12$ & $6.81 \pm 1.80$ & $7.48 \pm 2.51$ \\
\hline $\mathrm{C}$ & $6.93 \pm 2.52$ & $33.89 \pm 8.36$ & $0.59 \pm 0.09$ & $0.54 \pm 0.12$ & $0.53 \pm 0.10$ & $5.43 \pm 1.32$ & $5.96 \pm 1.01$ \\
\hline
\end{tabular}

\section{The biomass of understory vegetation}

It was known from Table 4 that the biomass of the shrubs of each type of reformed woodland was in the range of $0.53 \sim 0.82 \mathrm{t} . \mathrm{hm}^{-2}$ and those of the understory vegetation layer (shrub layer and herb layer) was $5.96 \sim 9.79 \mathrm{t} \cdot \mathrm{hm}^{-2}$. The order of the biomass of understory vegetation was $\mathrm{GX} 2>\mathrm{GX} 3>\mathrm{GX} 1>\mathrm{CT}>\mathrm{GX} 4>\mathrm{CT}$. The biomass of herbaceous layer ranged from 5.43 to $9.01 \mathrm{t} / \mathrm{hm}^{-2}$, and the order from largest to smallest 
was consistent with that of understory vegetation layer (shrub layer and herb layer). The biomass of shrub layer accounted for a small proportion of biomass of understory vegetation layer, only $7.96 \%-8.95 \%$, and herb layer accounted for $91 \%-92 \%$. Variance analysis showed that there was no significant difference between understory vegetation biomass in the same layer of different reforestation forests $(\mathrm{P}>0.05)$.

\section{Effects of different afforestation methods on soil physical properties}

The soil bulk density of the forest transformation types was $1.30 \mathrm{~g} \cdot \mathrm{cm}^{-3} \sim 1.64 \mathrm{~g} \cdot \mathrm{cm}^{-}$ 3. The soil bulk density of the Miyawaki Method 2 and the Miyawaki Method 4 was the largest, followed by the traditional method and the control, and the Soil bulk density of the Miyawaki Method 1 and the Miyawaki Method 3 was the smallest. The natural soil moisture content of the transformed forest had a significant difference $(\mathrm{P}<0.05)$, of which the Miyawaki Method 1 and the Miyawaki Method 2 were the largest, followed by the Miyawaki Method 3 and Miyawaki Method 4, and the traditional method and the control were the smallest. Among the various transformed forests, the soil bulk density and the natural soil moisture content were the highest in the Miyawaki Method 2, but the capillary soil water holding capacity and the capillary porosity were the largest in the Miyawaki Method 3, which were the lowest in the Miyawaki Method 2. The largest total porosity is the Miyawaki Method 1, and the smallest one is the Miyawaki Method 2. The non-capillary porosity and soil aeration porosity were the largest in the control plots, while they were the smallest in the Miyawaki Method 4 (Table 5). In an overall view, the effects of different afforestation methods on different soil physical properties were different. Compared with the traditional method and control, the natural soil moisture content could be increased more significantly through the Miyawaki Method, and in general, the soil capillary porosity increased after the afforestation compared with the control sample plots.

\section{Effects of different afforestation methods on soil chemical properties}

The soil chemical properties (Table 6) of different afforestation lands showed that there were significant differences in soil chemical indexes of different transformed forests, except for the available nitrogen content in the Miyawaki Method 3 and control, the soil acidity in the Miyawaki Method 4 and control woodland, and the available phosphorus content in the Miyawaki Method 2 and the Miyawaki Method 3. The Miyawaki Method 2 had the highest soil organic matter content, and $\mathrm{pH}$ value, which were $19.39 \mathrm{~g} \cdot \mathrm{kg}^{-1}$ and 5.22, respectively, and the Miyawaki Method 1 and the control had the lowest one, which was $6.06 \mathrm{~g} \cdot \mathrm{kg}^{-1}$ and 4.51 , respectively. The Miyawaki Method 3 had the highest soil available nitrogen and available potassium content, which were $70.67 \mathrm{mg} \cdot \mathrm{kg}^{-1}$ and $58.65 \mathrm{mg} \cdot \mathrm{kg}^{-1}$, respectively, and the Miyawaki Method $2 \mathrm{had}$ the lowest one, which was $25.94 \mathrm{mg} \cdot \mathrm{kg}^{-1}$ and $16.4 \mathrm{mg} \cdot \mathrm{kg}^{-1}$, respectively. The total soil phosphorus and available phosphorus content in the various woodlands transformed by traditional method were the highest, which were $0.26 \mathrm{~g} \cdot \mathrm{kg}^{-1}$ and $8.8 \mathrm{mg} \cdot \mathrm{kg}^{-1}$, respectively. The Miyawaki Method 1 and the Miyawaki Method 4 had the lowest total phosphorus and available phosphorus content, which were $0.14 \mathrm{~g} \cdot \mathrm{kg}^{-1}$ and $0.92 \mathrm{mg} \cdot \mathrm{kg}^{-1}$ respectively. The Miyawaki Method 3 and the Miyawaki Method 1 had the highest and the lowest soil total nitrogen in woodland, which was $0.91 \mathrm{~g} \cdot \mathrm{kg}^{-1}$ and $0.36 \mathrm{mg} \cdot \mathrm{kg}^{-1}$, respectively. 
Table 5. Soil Physics properties in different afforestation land

\begin{tabular}{|c|c|c|c|c|c|c|c|}
\hline $\begin{array}{l}\text { Afforestation } \\
\text { method }\end{array}$ & $\begin{array}{c}\text { Soil bulk density } \\
\left(\mathrm{g} \cdot \mathrm{cm}^{-3}\right)\end{array}$ & $\begin{array}{c}\text { Soil capillary } \\
\text { moisture capacity } \\
\left(\mathrm{g} \cdot \mathrm{kg}^{-1}\right)\end{array}$ & Total porosity $(\%)$ & $\begin{array}{c}\text { Capillary } \\
\text { porosity } \\
(\%)\end{array}$ & $\begin{array}{l}\text { Non-capillary } \\
\text { porosity }(\%)\end{array}$ & $\begin{array}{r}\text { Soil aeration } \\
\text { porosity }(\%)\end{array}$ & $\begin{array}{c}\text { Natural water } \\
\text { content }\left(\mathbf{g} \cdot \mathbf{k g}^{-1}\right)\end{array}$ \\
\hline MM1 & $1.30 \pm 0.07 \mathrm{c}$ & $264.99 \pm 4.98 \mathrm{a}$ & $51.05 \pm 2.77 \mathrm{a}$ & $34.39 \pm 2.45 \mathrm{a}$ & $16.65 \pm 5.19 \mathrm{ab}$ & $29.38 \pm 3.99 \mathrm{ab}$ & $167.04 \pm 0.00 \mathrm{a}$ \\
\hline MM2 & $1.64 \pm 0.12 \mathrm{a}$ & $170.31 \pm 20.08 \mathrm{~d}$ & $37.97 \pm 4.64 \mathrm{c}$ & $27.84 \pm 1.63 b$ & $10.13 \pm 3.71 b c$ & $23.33 \pm 5.73 b c$ & $189.07 \pm 0.00 \mathrm{~b}$ \\
\hline MM3 & $1.34 \pm 0.06 \mathrm{bc}$ & $270.27 \pm 13.47 \mathrm{a}$ & $49.28 \pm 2.24 \mathrm{ab}$ & $36.34 \pm 2.76 \mathrm{a}$ & $12.94 \pm 4.71 \mathrm{abc}$ & $28.80 \pm 3.14 \mathrm{ab}$ & $152.40 \pm 0.00 \mathrm{c}$ \\
\hline MM4 & $1.49 \pm 0.05 \mathrm{~b}$ & $236.50 \pm 7.67 \mathrm{~b}$ & $43.89 \pm 1.89 \mathrm{~b}$ & $35.14 \pm 0.76 \mathrm{a}$ & $8.75 \pm 2.30 \mathrm{c}$ & $19.71 \pm 2.70 \mathrm{c}$ & $162.69 \pm 0.00 \mathrm{~b}$ \\
\hline $\mathrm{T}$ & $1.39 \pm 0.08 b c$ & $252.58 \pm 20.39 a b$ & $47.43 \pm 2.86 \mathrm{ab}$ & $35.10 \pm 1.60 \mathrm{a}$ & $12.33 \pm 2.94 \mathrm{abc}$ & $26.34 \pm 4.00 \mathrm{abc}$ & $151.41 \pm 0.00 \mathrm{~d}$ \\
\hline $\mathrm{C}$ & $1.39 \pm 0.10 \mathrm{bc}$ & $210.30 \pm 9.60 \mathrm{c}$ & $47.66 \pm 3.83 \mathrm{ab}$ & $29.14 \pm 1.86 b$ & $18.52 \pm 5.40 \mathrm{a}$ & $33.44 \pm 4.88 \mathrm{a}$ & $102.55 \pm 0.00 \mathrm{e}$ \\
\hline
\end{tabular}

Table 6. Soil chemical properties in different afforestation lands

\begin{tabular}{|c|c|c|c|c|c|c|c|c|}
\hline $\begin{array}{l}\text { Afforestation } \\
\text { method }\end{array}$ & $\begin{array}{l}\text { Organic matter } \\
\qquad\left(\mathrm{g} \cdot \mathrm{kg}^{-1}\right)\end{array}$ & $\begin{array}{l}\text { Total nitrogen } \\
\left(\mathrm{g} \cdot \mathrm{kg}^{-1}\right)\end{array}$ & $\begin{array}{c}\text { Total } \\
\text { phosphorus } \\
\left(\mathrm{g} \cdot \mathrm{kg}^{-1}\right)\end{array}$ & $\begin{array}{c}\text { Total } \\
\text { potassium } \\
\left(\mathrm{g} \cdot \mathrm{kg}^{-1}\right)\end{array}$ & $\begin{array}{c}\text { Available } \\
\text { nitrogen } \\
\left.\text { N(mg· } \mathbf{k g}^{-1}\right)\end{array}$ & $\begin{array}{c}\text { Available } \\
\text { phosphorus } \\
\left(\mathrm{mg} \cdot \mathrm{kg}^{-1}\right)\end{array}$ & $\begin{array}{c}\text { Available } \\
\text { potassium } \\
\left(\mathrm{mg} \cdot \mathrm{kg}^{-1}\right)\end{array}$ & pH \\
\hline MM1 & $6.06 \pm 0.09 \mathrm{e}$ & $0.36 \pm 0.00 \mathrm{f}$ & $0.14 \pm 0.00 \mathrm{f}$ & $5.73 \pm 0.05 b$ & $29.52 \pm 0.12 d$ & $2.27 \pm 0.11 \mathrm{c}$ & $45.59 \pm 0.10 b$ & $5.19 \pm 0.00 \mathrm{~b}$ \\
\hline MM2 & $19.39 \pm 0.04 \mathrm{f}$ & $0.37 \pm 0.01 \mathrm{e}$ & $0.16 \pm 0.00 \mathrm{e}$ & $2.47 \pm 0.02 \mathrm{f}$ & $25.94 \pm 0.25 \mathrm{e}$ & $2.65 \pm 0.00 \mathrm{~b}$ & $16.94 \pm 0.20 \mathrm{f}$ & $5.22 \pm 0.01 \mathrm{a}$ \\
\hline MM3 & $17.46 \pm 0.49 \mathrm{a}$ & $0.91 \pm 0.02 \mathrm{a}$ & $0.25 \pm 0.01 b$ & $4.47 \pm 0.05 \mathrm{c}$ & $70.67 \pm 0.48 \mathrm{a}$ & $2.65 \pm 0.00 \mathrm{~b}$ & $58.65 \pm 0.23 a$ & $4.72 \pm 0.00 \mathrm{~d}$ \\
\hline MM4 & $9.93 \pm 0.05 \mathrm{~d}$ & $0.55 \pm 0.00 \mathrm{c}$ & $0.22 \pm 0.02 \mathrm{c}$ & $6.67 \pm 0.06 \mathrm{a}$ & $41.15 \pm 0.56 \mathrm{c}$ & $0.92 \pm 0.02 \mathrm{e}$ & $20.81 \pm 0.15 \mathrm{e}$ & $4.51 \pm 0.00 \mathrm{e}$ \\
\hline $\mathrm{T}$ & $11.64 \pm 0.03 c$ & $0.38 \pm 0.01 \mathrm{~d}$ & $0.26 \pm 0.04 \mathrm{a}$ & $2.69 \pm 0.07 \mathrm{e}$ & $59.04 \pm 0.45 b$ & $8.8 \pm 0.03 \mathrm{a}$ & $27.45 \pm 0.45 \mathrm{~d}$ & $5.08 \pm 0.00 \mathrm{c}$ \\
\hline $\mathrm{C}$ & $17.06 \pm 0.28 b$ & $0.81 \pm 0.01 \mathrm{~b}$ & $0.18 \pm 0.01 \mathrm{~d}$ & $3.75 \pm 0.02 \mathrm{~d}$ & $70.67 \pm 0.78 \mathrm{a}$ & $2.08 \pm 0.00 \mathrm{~d}$ & $40.29 \pm 0.89 c$ & $4.51 \pm 0.00 \mathrm{e}$ \\
\hline
\end{tabular}


The Miyawaki Method 4 and the Miyawaki Method 2 had the highest and the lowest soil total potassium content, which was $6.67 \mathrm{~g} \cdot \mathrm{kg}^{-1}$ and $2.47 \mathrm{~g} \cdot \mathrm{kg}^{-1}$, respectively. The comprehensive analysis showed that the soil nutrient content of afforestation land through the Miyawaki Method 3 was higher than that of other woodlands.

\section{Effects of different afforestation methods on soil microbial quantity}

The number of bacteria, fungus and actinomycetes in soil of 6 different afforestation land showed that: the number of 3 microbes in soil was obviously different, and the number order was bacteria $>$ actinomycetes $>$ fungus (Table 7 ). The number of bacteria, fungus and actinomycetes in the soil of different afforestation lands showed significant difference. From the number of soil bacteria, the afforestation land through the Miyawaki Method 3 was significantly higher than that of other woodlands, which was $6.69 \times 10^{5} \mathrm{CFU} / \mathrm{g} \cdot \mathrm{soil}$, and the smallest one was the land transformed by the Miyawaki Method 4, which was $0.04 \times 10^{5} \mathrm{CFU} / \mathrm{g}$. soil. From the number of soil fungus, the afforestation land through Miyawaki Method 3 and the traditional method were significantly higher than that of other woodlands, which were $1.55 \times 10^{3} \mathrm{CFU} / \mathrm{g} \cdot$ soil and $1.32 \times 10^{3} \mathrm{CFU} / \mathrm{g} \cdot$ soil, respectively. However, the lowest one was the land transformed by the Miyawaki Method 1 and the Miyawaki Method 4, which was $0.08 \times 10^{3}$ $\mathrm{CFU} / \mathrm{g}$-soil. The number of soil actinomycetes was basically the same as that of fungus, showing that the afforestation and through Miyawaki Method 3 and traditional methods were higher than that of other woodlands, which were $2.49 \times 10^{4} \mathrm{CFU} / \mathrm{g} \cdot \mathrm{soil}$ and $1.98 \times 10^{4} \mathrm{CFU} / \mathrm{g} \cdot$ soil respectively, while the lowest one was the land transformed by the Miyawaki Method 1 and Miyawaki Method 4, which was $0.1 \times 10^{4} \mathrm{CFU} / \mathrm{g} \cdot \mathrm{soil}$ and $0.21 \times 10^{4} \mathrm{CFU} / \mathrm{g} \cdot$ soil respectively. From the above results, it can be known that the number of bacteria, fungus and actinomycetes in the soil in the woodlands transformed by the Miyawaki Method 3 was the highest, and the lowest one was the land transformed by the Miyawaki Method 1 and the Miyawaki Method 4.

Table 7. Soil microbial number in different afforestation lands

\begin{tabular}{c|c|c|c}
\hline Afforestation method & $\begin{array}{c}\text { Bacteria } \\
\left(\mathbf{1 0}^{\mathbf{5}} \mathbf{C F U} / \mathbf{g} \cdot \mathbf{s o i l}\right)\end{array}$ & $\begin{array}{c}\text { Fungi } \\
(\mathbf{1 0} \mathbf{C F U} / \mathbf{g} \cdot \mathbf{s o i l})\end{array}$ & $\begin{array}{c}\text { Actinomycetes } \\
(\mathbf{1 0} \mathbf{~ C F U} / \mathbf{g} \cdot \mathbf{s o i l})\end{array}$ \\
\hline MM1 & $0.14 \pm 0.08 \mathrm{e}$ & $0.08 \pm 0.04 \mathrm{e}$ & $0.10 \pm 0.05 \mathrm{f}$ \\
\hline MM2 & $0.80 \pm 0.27 \mathrm{~b}$ & $0.16 \pm 0.08 \mathrm{~d}$ & $0.54 \pm 0.12 \mathrm{~d}$ \\
\hline MM3 & $6.69 \pm 1.42 \mathrm{a}$ & $1.55 \pm 0.56 \mathrm{a}$ & $2.49 \pm 0.89 \mathrm{a}$ \\
\hline MM4 & $0.04 \pm 0.02 \mathrm{f}$ & $0.08 \pm 0.02 \mathrm{f}$ & $0.21 \pm 0.12 \mathrm{e}$ \\
\hline T & $0.44 \pm 0.21 \mathrm{~d}$ & $1.32 \pm 0.38 \mathrm{~b}$ & $1.98 \pm 0.90 \mathrm{~b}$ \\
\hline C & $0.61 \pm 0.32 \mathrm{c}$ & $0.65 \pm 0.25 \mathrm{c}$ & $1.71 \pm 0.78 \mathrm{c}$ \\
\hline
\end{tabular}

\section{Effects of different afforestation methods on soil enzyme activity}

As for the soil enzyme activity of six different sample plots (Figure 3, Figure 4 and Figure 5), there was the highly significant difference $(\mathrm{P}<0.05)$. For urease activity, it was in the range of $56.87 \sim 189.50 \mathrm{mg} \cdot \mathrm{kg}^{-1}$. The urease activity of Miyawaki Method 3, traditional and control was significantly higher than others, and the Miyawaki Method afforestation had the lowest activity with $56.87 \mathrm{mg} \cdot \mathrm{kg}^{-1}$. As for the acid phosphatase activity, the woodland transformed with Miyawaki Method 3 was the highest, namely 
$285.10 \mathrm{mg} \cdot \mathrm{kg}^{-1}$, while those with the Miyawaki Method 2 was the lowest with the 67.43 $\mathrm{mg} \cdot \mathrm{kg}^{-1}$. As to catalase, the control and the plot transformed with Miyawaki Method 3 were significantly higher than other plots, which were $1.87 \mathrm{~mL} \cdot \mathrm{g}^{-1}$ and $1.76 \mathrm{~mL} \cdot \mathrm{g}^{-1}$, respectively, while those with the Miyawaki Method 2 and traditional method were the lowest, that were $0.75 \mathrm{~mL} \cdot \mathrm{g}^{-1}$ and $0.88 \mathrm{~mL} \cdot \mathrm{g}^{-1}$. To sum up, the woodland transformed with Miyawaki Method 3 and control had the highest soil urease, phosphatase and catalase activity. The soil enzymatic activity of the land transformed with Miyawaki Method 2 and Miyawaki Method 1 was the lowest in the six different plantation lands except the catalase activity of the land transformed with the Miyawaki Method 1 was slightly higher than the plots transformed with traditional method.

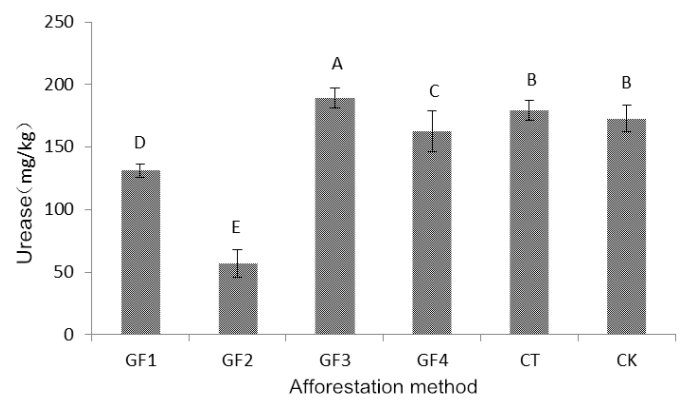

Figure 3. Soil urease activity of different forestlands

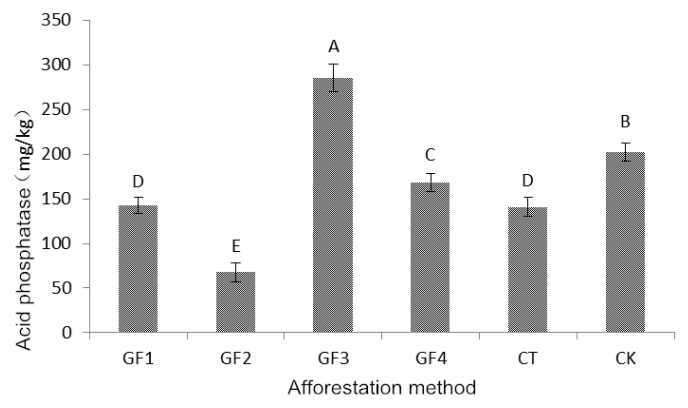

Figure 4. Soil acid phosphatase activity of different forestlands

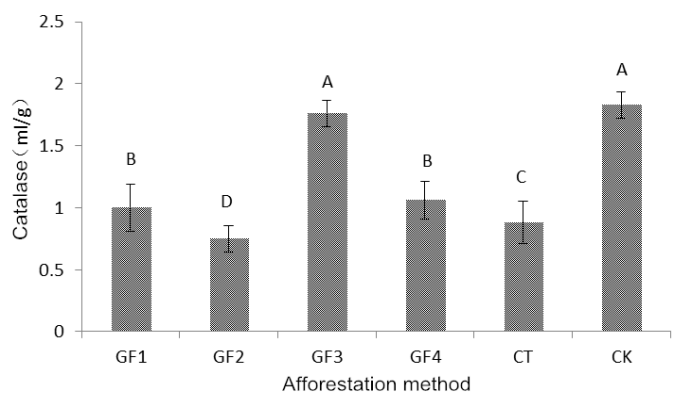

Figure 5. Soil catalase activity of different forestlands

\section{Comprehensive evaluation of soil quality of woodlands transformed with different afforestation methods}

As shown in Table 8 for the characteristic value and variance contribution rate of every principal component, the characteristic value of the first four principal components was larger than 1 , and their variance contribution rates were $52.442 \%$, $20.692 \%, 14.645 \%$ and $8.147 \%$ respectively, and the cumulative contribution rate was $95.926 \%$. Soil bulk density, total porosity, total nitrogen, available nitrogen, available potassium, bacteria, fungus, actinomycetes, urease, phosphatase and catalase had relatively high factor loading for the principal component. Organic matter and total potassium had relatively high factor loading in the principal component 2 , and available phosphorus had a higher factor loading in the principal component, and natural moisture content had a higher factor loading in the principal component. 
Table 8. Results of principal component analysis

\begin{tabular}{c|c|c|c|c}
\hline Soil Quality Index & $\begin{array}{c}\text { Principal } \\
\text { component 1 }\end{array}$ & $\begin{array}{c}\text { Principal } \\
\text { component 2 }\end{array}$ & $\begin{array}{c}\text { Principal } \\
\text { component 3 }\end{array}$ & $\begin{array}{c}\text { Principal } \\
\text { component 4 }\end{array}$ \\
\hline Soil bulk density & -0.701 & 0.566 & 0.363 & -0.09 \\
\hline Total porosity & 0.693 & -0.584 & -0.354 & 0.075 \\
\hline Natural water content & -0.699 & 0.034 & -0.002 & 0.70 \\
\hline Organic matter & 0.195 & 0.864 & 0.449 & -0.02 \\
\hline Total nitrogen & 0.85 & 0.111 & 0.501 & -0.09 \\
\hline Total potassium & 0.049 & -0.881 & 0.318 & 0.053 \\
\hline Available nitrogen & 0.921 & 0.246 & -0.079 & -0.27 \\
\hline Available phosphorus & 0.078 & 0.392 & -0.914 & 0.015 \\
\hline Available potassium & 0.817 & -0.282 & 0.068 & 0.353 \\
\hline Bacteria & 0.694 & 0.258 & 0.27 & 0.611 \\
\hline Fungi & 0.777 & 0.433 & -0.372 & 0.225 \\
\hline Actinomycetes & 0.823 & 0.521 & -0.221 & 0.039 \\
\hline Urease & 0.836 & -0.252 & -0.263 & -0.19 \\
\hline Phosphatase & 0.94 & -0.156 & 0.219 & 0.121 \\
\hline Catalase & 0.881 & -0.01 & 0.403 & -0.21 \\
\hline
\end{tabular}

The corresponding feature vector of four main components can be calculated based on the factor loading and characteristic value of various variates in their principal components. As for the matrix of initial factor loading (Table 9), the expressions of PC1, PC2, PC3 and PC4 can be calculated by every feature vector multiplying by standardized data (PC1, PC2, PC3 and PC4 indicated the first four principal components respectively):

$$
\begin{aligned}
& \mathrm{F} 1=-0.25 \mathrm{X} 1+0.25 \mathrm{X} 2-0.25 \mathrm{X} 3+0.07 \mathrm{X} 4+0.3 \mathrm{X} 5+0.02 \times 6+0.33 \times 7+0.03 \times 8+0.29 \times 9 \\
& +0.25 \mathrm{X} 10+0.28 \mathrm{X} 11+0.29 \mathrm{X} 12+0.3 \mathrm{X} 13+0.34 \mathrm{X} 14+0.31 \mathrm{X} 15 \\
& \mathrm{~F} 2=0.32 \times 1-0.33 \times 2+0.02 \times 3+0.49 \times 4+0.06 \times 5-0.5 \times 6+0.14 \times 7+0.22 \times 8-0.16 \times 9 \\
& +0.15 \times 10+0.25 \times 11+0.3 \times 12-0.14 \times 13-0.09 \times 14-0.01 \times 15 \\
& \mathrm{~F} 3=0.24 \mathrm{X} 1-0.24 \mathrm{X} 2+0 * \mathrm{X} 3+0.3 \mathrm{X} 4+0.34 \times 5+0.21 \times 6-0.05 \times 7-0.62 \times 8+0.05 \times 9 \\
& +0.18 \times 10-0.25 \times 11-0.15 \times 12-0.18 \times 13+0.15 \times 14+0.27 \times 15 \\
& \mathrm{~F} 4=-0.08 \times 1+0.07 \times 2+0.63 \times 3-0.02 \times 4-0.08 \times 5+0.05 \times 6-0.24 \times 7+0.01 \times 8+0.32 \times 9 \\
& +0.55 \times 10+0.2 \times 11+0.04 \times 12-0.17 \times 13+0.11 \times 14-0.19 \times 15
\end{aligned}
$$

The standardized data were brought into the above four principal component expressions respectively, and the scores of four principal components of woodland soil transformed with different afforestation methods were obtained. Then, according to $\mathrm{F}=\Sigma \mathrm{biFi}=\mathrm{a} 1 \mathrm{~F} 1+\mathrm{a} 2 \mathrm{~F} 2+\ldots+\mathrm{ajFj}, \mathrm{F}$ was the comprehensive principal component score, $\mathrm{F} 1, \mathrm{~F} 2 \ldots \mathrm{Fj}$ was the value of each principal component and a1, a2... .aj was the ratio of the eigenvalues of each principal component to the sum of the extracted principal component eigenvalues, respectively. We got exactly that:

$$
\begin{aligned}
\mathrm{F}= & -0.038 \mathrm{X} 1+0.035 \mathrm{X} 2-0.079 \times 3+0.188 \times 4+0.222 \times 5-0.061 \times 6+0.183 \times 7-0.03 \times 8 \\
& +0.159 \times 9+0.243 \times 10+0.186 \times 11+0.204 \times 12+0.092 \times 13+0.199 \times 14+0.193 \times 15
\end{aligned}
$$


$\mathrm{X} 1$ represents Soil bulk density, X2 for total porosity, X3 for natural moisture content, $\mathrm{X} 4$ for organic matter, $\mathrm{X} 5$ for total nitrogen, $\mathrm{X} 6$ for total potassium, $\mathrm{X} 7$ for available nitrogen, $\mathrm{X} 8$ for available phosphorus, $\mathrm{X} 9$ for available potassium, X10 for urease, X11 for phosphatase, X12 as catalase, X13 as bacteria, X14 as fungus and X15 as actinomycetes.

Table 9. Component matrix

\begin{tabular}{c|c|c|c}
\hline $\begin{array}{c}\text { Principal } \\
\text { component }\end{array}$ & Eigenvalue & Contribution ratio (\%) & $\begin{array}{c}\text { Accumulative } \\
\text { contribution ratio (\%) }\end{array}$ \\
\hline Factor 1 & 7.866 & 52.442 & 52.442 \\
\hline Factor 2 & 3.104 & 20.692 & 73.134 \\
\hline Factor 3 & 2.197 & 14.645 & 87.779 \\
\hline Factor 4 & 1.222 & 8.147 & 95.926 \\
\hline
\end{tabular}

From the comprehensive principal component value (Table 10, $\mathrm{Z1}-4$ and $\mathrm{Z}$ in Table 10 indicated the comprehensive score of the principal component $1,2,3,4$ and their sum for each afforestation method respectively), it was known that the rank of the soil comprehensive quality of afforestation types was as follows: Miyawaki Method 3(0.05) $>$ Miyawaki Method1(0.04) $>$ Miyawaki Method 2(0.12) $>\operatorname{traditional(-0.04)>}$ Miyawaki Method 4(-0.02)>control(-0.15).

Table 10. Scores of principal components

\begin{tabular}{c|c|c|c|c|c|c}
\hline $\begin{array}{c}\text { Afforestation } \\
\text { method }\end{array}$ & $\mathbf{Z 1}$ & $\mathbf{Z 2}$ & $\mathbf{Z 3}$ & $\mathbf{Z 4}$ & $\mathbf{Z}$ & Ranking \\
\hline MM1 & 0 & -2.69 & -0.57 & 0.64 & 0.05 & 2 \\
\hline MM2 & -3.87 & 2.17 & 0.9 & 0.45 & 0.04 & 3 \\
\hline MM3 & 4.04 & 0.59 & 0.79 & 1.41 & 0.12 & 1 \\
\hline MM4 & -1.45 & -1.44 & 0.92 & -0.49 & -0.04 & 5 \\
\hline T & 0.23 & 1.04 & -2.79 & -0.23 & -0.02 & 4 \\
\hline C & 2.17 & 0.32 & 0.75 & -1.79 & -0.15 & 6 \\
\hline
\end{tabular}

\section{Discussion}

\section{Understory vegetation characteristics of different afforestation woodland}

Stand density directly affects the allocation of light, heat and moisture in forest stands, resulting in resource competition between trees and understory vegetation (Chen et al., 2014). Fertilization methods can regulate soil structure and nutrient content, and also indirectly affect understory vegetation (Haywood et al., 2012). It was found that there were differences in the understory vegetation characteristics in different types of reformed woodlands. The changes in the average coverage of the shrub layer and herb layer in different woodlands were the same that Miyawaki Method 3 was the largest, followed by Miyawaki Method 2, and the least in the control woodland. The total biomass of the understory vegetation and the biomass of the herb layer showed the same trend, and Miyawaki Method 2 was the largest, the next was Miyawaki Method 3 and 
control woodland was the smallest among them. This indicated that Miyawaki Method 2 and Miyawaki Method 3 were most beneficial to the growth of the undergrowth vegetation. The proportion of shrub layer to the biomass of understory vegetation was small, which might be related to the effect of soil erosion on soil seed bank before forestation. Besides, most of the vegetation in herb layer was Dicranopteris pedata. Because of its strong rhizomatous fecundity and rapid growth characteristics (Yang et al., 2017). Therefore, the herbaceous layer dominated the understory vegetation characteristics. Although there was no significant difference in the biomass of vegetation in different afforestation woodlands $(\mathrm{P}>0.05)$. On the whole, the biomass of the understory vegetation layer in the woodland with good soil quality was larger than that with poor soil quality, which was by the results of some other scholars (Fabião et al., 2002; Yang et al., 2017).

\section{Soil physical properties of different afforestation method}

Soil physical properties are important factors to reflect comprehensive soil quality, and good or bad physical properties are determined by the soil bulk density, soil porosity, capillary water and natural soil moisture content together. Different utility patterns of woodlands affect the scale soil bulk density (Dadhwal et al., 2011). In this research for different afforestation methods in this paper, there wasn't any significant difference in soil bulk density, capillary water holding capacity, total porosity, capillary porosity and aeration porosity, except the significant difference in natural soil moisture content. Soil bulk density and natural soil moisture content were relatively higher in the transformed plots with Miyawaki Method 2, which showed that it has the best performance in keeping compaction structure and soil moisture. But as to the capillary water holding capacity and soil porosity, woodland transformed with Miyawaki Method 2 was low, and that with Miyawaki Method 3 was the highest. In general, Miyawaki Method was more beneficial to the optimization of keeping soil physical properties, which would be related to the afforestation density of Miyawaki Method and fertilization modes. There was a large canopy density in Miyawaki Method 2. The growth of vegetation was good, conservation effect of water and soil was better, and was more beneficial to the soil interstices and conservation of soil moisture content.

\section{Soil chemical properties of different afforestation method}

The basic chemical property factors that were used to evaluate comprehensive soil quality include Organic matters, total $\mathrm{N}$, total $\mathrm{P}$, total $\mathrm{K}$ and available $\mathrm{N}$, available $\mathrm{P}$ and available potassium and $\mathrm{pH}$, etc. Soil nutrient had a close association with the growth and development of vegetation on the ground (Fernández-Fernández et al., 2015). Vegetation cover can increase the total nitrogen and organic matter content after farmland returning to woodland (Cheng et al., 2015). There were significant chemical properties in woodlands transformed with different afforestation methods. Wherein, the woodlands which had the highest soil organic matter content were those transformed with Miyawaki Method 2. Forestlands in which the total nitrogen, available nitrogen, available potassium were the highest were the plantations transformed with Miyawaki Method 3. And one in which total phosphorus and available phosphorus were the highest was the transformed plots with traditional method. In the comprehensive consideration, forestlands transformed with Miyawaki Method 3 had the highest soil moisture content, which showed that afforestation method of Miyawaki Method 3 was more beneficial to the improvement of soil fertility. The reason would be the large 
density of plantation transformed with Miyawaki Method 2 and Miyawaki Method 3, with rich vegetation, as well as rich contents in litters on the surface layer of the forest, therefore microorganism entered into the soil after decomposition and richened soil nutrient.

\section{Soil biological properties of different afforestation method}

Soil biological properties would flexibly reflect soil quality and change condition of health degree (Riches et al., 2013). Enzymatic activity of soil and microorganisms would consider as an important factor to reflect soil biological properties (Huang et al., 2012; Coppolecchia et al., 2011). Soil enzyme plays an important role in the biochemical reaction of soil (Salazar et al., 2011), has a close relationship with soil fertility. Soil microorganism is a key indicator to measure comprehensive quality (Askari et al., 2015; Wu et al., 2013). Compared with soil nutrients, it was more reasonable to use soil enzyme activity and soil microorganisms number to evaluate soil nutrients (Liu et al., 2015; Li et al., 2015). In the research, the number of bacteria, fungus and actinomycetes in the soil in the woodlands transformed by the Miyawaki Method 3 was the highest, and the lowest one was the land transformed by the Miyawaki Method 1 and the Miyawaki Method 4. The soil enzyme activity of the land transformed with Miyawaki Method 3 and control was significantly higher than other transformed plots, and while those with Miyawaki Method 2 and Miyawaki Method 1 were the lowest. There wasn't any obvious correlation between soil enzyme activity and soil microorganism, which would be related to the too short afforestation age of investigated plots and excessive man-made interference.

\section{A comprehensive evaluation of soil quality of woodlands transformed with different afforestation methods}

The pincipal component analysis was used to discuss the effect of Miyawaki Method and traditional method on soil quality of woodlands. On matter, Miyawaki Method or traditional afforestation, soil quality after stand improvement were higher than those of control plots without transformation, which showed that stand improvement were conducive to the improvement of oil quality in woodlands. Compared with traditional method and Miyawaki Method 2 afforestation method, soil quality of the forestlands transformed with other three Miyawaki Methods was higher than the lands transformed with traditional methods except that comprehensive soil quality of the woodlands transformed with Miyawaki Method 4 was slightly lower than plots transformed with traditional method. The above sentences showed improvement efficiency of Miyawaki Method was better than that of traditional method. Comparison of soil efficiency of improvement of four kinds of Miyawaki Methods, improvement efficiency of Miyawaki Method 3 was the best, followed by Miyawaki Method 2 and Miyawaki Method. Whereas, Miyawaki Method 3 and Miyawaki Method 2 are main recommended methods for the stand transformation in this area. It can provide a reference basis for the transformation work of the forest stand.

In this study, the efficiency of improvement of Miyawaki Method 3 for soil quality was the best, and there were differentiated in the planting density and fertilization methods of the four kinds of Miyawaki Method and showed that reasonable planting density and fertilization methods should be set based on actual conditions during afforestation. Due to the short period of afforestation, the great influence of human 
intervention on woodland and lack of quantitative observation, a long-term observation at six-point and position under eliminations of external interference need to be carried out as far as possible if we if we have more reasonable discussions on afforestation methods' effects on soil quality of woodlands to get sufficient and effective experimental data.

\section{Conclusion}

1. The average coverage of shrub layer and herb layer in different transformed forests were arranged in order: GX3 $>\mathrm{GX} 2>\mathrm{CT}>\mathrm{GX} 1>\mathrm{GX} 4>\mathrm{CK}$. While, the average height difference was not obvious. The order of the biomass of understory vegetation was $\mathrm{GX} 2>\mathrm{GX} 3>\mathrm{GX} 1>\mathrm{CT}>\mathrm{GX} 4>\mathrm{CT}$. The biomass of herb layer accounted for a large proportion of biomass of understory vegetation layer.

2. Soil bulk density and natural soil moisture content were relatively higher in the transformed plots with Miyawaki Method 2. But as to the capillary water holding capacity and soil porosity, woodland transformed with Miyawaki Method 3 was the highest. In all, Miyawaki Method 2 afforestation was better for preserving soil physical properties, but with little difference.

3. Total nitrogen, available nitrogen, available potassium in the woodlands transformed with Miyawaki Method 3 were the highest, and one in which total phosphorus and available phosphorus was the highest was the transformed plots with traditional method. In all, afforestation method of Miyawaki Method 3 was more beneficial to the improvement of soil fertility than other methods.

4. The number of bacteria, fungus and actinomycetes in the soil in the woodlands transformed by the Miyawaki Method 3 was the highest, and the lowest one was the land transformed by the Miyawaki Method 1 and the Miyawaki Method 4. The soil enzyme activity of the land transformed with Miyawaki Method 3 and control was significantly higher than other transformed plots, and while those with Miyawaki Method 2 and Miyawaki Method 1 were the lowest.

5. The results of principal component analysis showed that forest improvement could effectively improve the soil quality, and the effect of Miyawaki Method 3 was the best.

Acknowledgements. The author thanks China West Normal University Doctoral Startup Research Project (412666).

\section{REFERENCES}

[1] Akca, E., Kapur, S., Tanaka, Y., Kaya, Z., Bedestenci, H. C., Yakti, S. (2010): Afforestation effect on soil quality of sand dunes. - Polish Journal of Environmental Studies 19:1109-1116.

[2] Askari, M. S., Holden, N. M. (2015): Quantitative soil quality indexing of temperate arable management systems. - Soil \& Tillage Research 150: 57-67.

[3] Berthrong, S. T., Jobbagy, E. G., Jackson, R. B. (2009): A global meta-analysis of exchangeable soil cations, $\mathrm{pH}$, carbon, and nitrogen with afforestation. - Ecol Appl 19: 2228-2241.

[4] Chen, C. R., Condron, L. M., Xu, Z. H. (2008): Impacts of grassland afforestation with coniferous trees on soil phosphorus dynamics and associated microbial processes: A review. - Forest Ecology and Management 255: 396-409. 
[5] Chen, Y., Cao, Y., Chen, Y., Cao, Y. (2014): Response of tree regeneration and understory plant species diversity to stand density in mature Pinus tabulaeformis plantations in the hilly area of the Loess Plateau, China. - Ecological Engineering 73: 238-245.

[6] Cheng, M., An, S. S. (2015): Responses of soil nitrogen, phosphorous and organic matter to vegetation succession on the Loess Plateau of China. - Journal of Arid Land 7: 216223.

[7] Coppolecchia, D., Puglisi, E., Vasileiadis, S., Suciu, N., Hamon, R., Beone, G. M., Trevisan, M. (2011): Relative sensitivity of different soil biological properties to zinc. Soil Biology \& Biochemistry 43: 1798-1807.

[8] Dadhwal, K. S., Debashis, M., Srimali, S. S., Dhyani, S. K., Mohan, S. C., Raizada, A. (2011): Landscape-scale soil quality assessment under different land use systems in north-western hilly region. - Indian Journal of Soil Conservation 39: 128-135.

[9] Fabião, A., Martins, M. C., Cerveira, C., Santos, C., Lousã, M., Madeira, M., Correia, A. (2002): Influence of soil and organic residue management on biomass and biodiversity of understory vegetation in a Eucalyptus globulus Labill. Plantation. - Forest Ecology \& Management 171: 87-100.

[10] Fernández-Fernández, M., Gómez-Rey, M. X., González-Prieto, S. J. (2015): Effects of fire and three fire-fighting chemicals on main soil properties, plant nutrient content and vegetation growth and cover after ten years. - Science of the Total Environment 92: 515516.

[11] Haywood, J. D. (2012): Pine Straw Harvesting, Fire, and Fertilization Affect Understory Vegetation within a Louisiana Longleaf Pine Stand. - Southern Journal of Applied Forestry 36: 130-135.

[12] Huang, L., Gao, X., Liu, M., Du, G., Guo, J., Ntakirutimana, T. (2012): Correlation among soil microorganisms, soil enzyme activities, and removal rates of pollutants in three constructed wetlands purifying micro-polluted river water. - Ecological Engineering 46: 98-106.

[13] Jaurixje, M., Torres, D., Mendoza, B., Henríquez, M., Contreras, J. (2013): Physical and chemical soil properties and their relation with biological activity under different soil managements in Quíbor, Lara State, Venezuela. - Bioagro 25:47-56.

[14] Li, J., Zhou, X., Yan, J., Li, H., He, J. (2015): Effects of regenerating vegetation on soil enzyme activity and microbial structure in reclaimed soils on a surface coal mine site. Applied Soil Ecology 87: 56-62.

[15] Liu, D., Liu, Y., Fang, S., Tian, Y. (2015): Tree species composition influenced microbial diversity and nitrogen availability in rhizosphere soil. - Plant Soil \& Environment 61: 438-443.

[16] Miyawaki, A., Golley, F. B. (1993): Forest reconstruction as ecological engineering. Ecological Engineering 2: 333-345.

[17] Miyawaki, A. (1998): Restoration of urban green environments based on the theories of vegetation ecology. - Ecological Engineering 11: 157-165.

[18] Miyawaki, A. (1999): Creative ecology: restoration of native forests by native trees. Plant Biotechnol 16: 15-25.

[19] Miyawaki, A. (2010): Restoration of living environment based on vegetation ecology: theory and practice. - Ecol Res 19: 83-90.

[20] Ranjbar, A., Emami, H., Khorasani, R., Karoyeh, A. R. K. (2016): Soil quality assessments in some Iranian saffron fields. - Journal of Agricultural Science \& Technology.

[21] Riches, D., Porter, I. J., Oliver, D. P., Bramley, R. G. V., Rawnsley B., Edwards, J., White, R. E. (2013): Review: soil biological properties as indicators of soil quality in Australian viticulture. - Australian Journal of Grape \& Wine Research 19: 311-323.

[22] Rodrigues, R. R., Lima, R. A. F., Gandolfi, S., Nave, A. G. (2009): On the restoration of high diversity forests: 30 years of experience in the Brazilian Atlantic Forest. - Biological 
Conservation 142: 1242-1251.

[23] Salazar, S., Sánchez, L. E., Alvarez, J., Valverde, A., Galindo, P., Igual, J. M., Peix, A., Santa-Regina, I. (2011): Correlation among soil enzyme activities under different forest system management practices. - Ecological Engineering 37: 1123-1131.

[24] Schirone, B., Salis, A., Vessella, F. (2011): Effectiveness of the Miyawaki method in Mediterranean forest restoration programs. - Landscape \& Ecological Engineering 7: 8192.

[25] Schoenholtz, S. H., Van Miegroet, H., Burger, J. A. (2000): A review of chemical and physical properties as indicators of forest soil quality: challenges and opportunities. Forest Ecology and Management 138: 335-356.

[26] Wang, F., Xiong, S. G., Li, H. Y., He, M. X. (2014): Study on Dust-Retention Ability of Major Afforestation Tree Species in New Industrial Zone. - Advanced Materials Research 838-841: 2433-2438.

[27] Wu, R., Liu, G., Kan, Y., Shao, X. (2013): Dynamics of soil microbial structure and its potential to indicate soil quality during natural restoration and succession processes in the Inner Mongolia Steppe. - Journal of Food Agriculture \& Environment 11: 2265-2272.

[28] Yang, B., Li, Y., Ding, B., Both, S., Erfmeier, A., Härdtle, W., Ma, K., Schmid, B., Scholten, T., Seidler, G., Oheimb, G. V., Yang, X. F., Bruelheide, H. (2017): Impact of tree diversity and environmental conditions on the survival of shrub species in a forest biodiversity experiment in subtropical China. - Journal of Plant Ecology 10: 179-189.

[29] Yang, X., Li, D., Mcgrouther, K., Long, W. X., Li, Y. L., Chen, Y. K., Lv, X. B., Niazi, N. K., Song, Z. L., Wang, H. L. (2017): Effect of Eucalyptus, forests on understory vegetation and soil quality. - Journal of Soils \& Sediments 17: 2383-2389.

[30] Zhao, X., Jia, S., Li, M., Liu, Y., Su, T. C. (2014): Soil Quality Assessment by TOPSIS Method Based on PCA in the Afforested Coal Gangue Area. - Journal of Northeast Forestry University. 